\section{Random Amplified Polymorphic DNA Analysis of Dry Turfgrass Seed}

\author{
Patricia Sweeney ${ }^{1}$, Robert Golembiewski, and Karl Danneberger \\ Department of Horticulture and Crop Science, The Ohio State University, \\ Columbus, $\mathrm{OH} 43210$
}

Additional index words. arbitrarily primed PCR, DNA fingerprint, cultivar identification, varietal identification, seed testing

\begin{abstract}
Random amplified polymorphic DNA (RAPD) markers from leaf tissue extractions are effective for discrimination of turfgrass varieties. The usefulness of RAPD markers for turfgrass variety identification can be enhanced by use of seed rather than leaf tissue for DNA extraction. To determine whether DNA extracted from turfgrass seed was suitable for amplification, DNA was extracted from bulk samples and individual seeds of bermudagrass [Cynodon dactylon (L.) Pers.], chewings fescue (Festuca rubra var. commutata Gaud.), Poa annua L., Poa supina Schrad., creeping bentgrass [Agrostis stolonifera L. var. palustrus (Huds.) Farw.], Kentucky bluegrass (Poa pratensis L.), perennial ryegrass (Lolium perenne L.), and tall fescue (Festuca arundinacea Schreb.). All samples were successfully amplified using an arbitrary primer. Amplification intensity varied among species. With an almost infinite number of arbitrary primers available, it is likely that suitable primers can be found to amplify DNA from most turfgrass species. Amplification of turfgrass seed DNA, whether bulk or individual seed, is possible and should prove more useful than amplification of leaf tissue DNA for discrimination of turfgrass varieties.
\end{abstract}

The need for improved methods of variety identification of turfgrass species is increasing due to the large number of varieties released each year. The ability to extract DNA from a single seed may be an important factor in variety identification procedures. To our knowledge, amplification of turfgrass seed DNA has not been reported. Caetano-Anolles et al.(1991), Weaver etal. (1995), and Sweeney and Danneberger (1994) extracted DNA for amplification from leaf tissue. The need for using leaf tissue hinders the use of analyses involving DNA amplification in a routine seed testing laboratory where variety identification is practiced, since the time required to grow tissue may exceed 7 days. McDonald et al. (1994) reported a procedure for extracting DNA from dry seed of several species for amplification with arbitrary primers. We, therefore, studied whether 1) amplification procedures described by McDonald et al. are suitable for turfgrass seed and 2) DNA extracted from a single seed could be amplified.

Received for publication 15 Sept. 1995. Accepted for publication $29 \mathrm{Feb}$. 1996. This research was supported by the Ohio Agricultural Research and Development Center Project no. 205-95. Salaries and research support provided by state and federal funds appropriated to the Ohio Agricultural Research and Development Center, Ohio State Univ. Additional support provided by the OhioTurfgrass Foundation. Use of trade names does not imply endorsement of the products named to the exclusion of other similar products. The cost of publishing this paper was defrayed in part by the payment of page charges. Under postal regulations, this paper therefore must be hereby marked advertisement solely to indicate this fact.

${ }^{1}$ To whom reprint requests should be addressed. ing bentgrass, 'America' and 'Bronco' Kentucky bluegrass, 'Caravelle' and 'Accolade' perennial ryegrass, and 'Arid' and 'Finelawn 1 ' tall fescue were placed in a mechanical scarifier (Fred Forsberg and Son, Thief River Falls, Minn.) for $2 \mathrm{~min}$, then transferred to a vacuum blower for $2 \mathrm{~min}$ to remove remaining chaff. Seed size varies from $14 \times 10^{3}$ seed/ gram for creeping bentgrass to 500 for tall fescue (Turgeon, 1990). For each scarified sample, DNA was extracted from a $20-\mathrm{mg}$ bulk sample and a single seed using a modified Edwards et al. (1991) procedure (Sweeney and Danneberger, 1994). Estimates of DNA concentrations of extracts from the bulk samples were made using a TKO $100 \mathrm{Mini}$ Fluorometer (Hoefer Scientific Instruments, San Francisco) and ranged from 6 to 31 $\mu \mathrm{g} \cdot \mathrm{mL}^{-1}$. Bulk DNA extractions were diluted with Tris EDTA (TE) [10 mm Tris- $\mathrm{HCl}, \mathrm{pH}$ $7.5,1 \mathrm{~mm}$ EDTA] to 2 to $5 \mu \mathrm{g} \cdot \mathrm{mL}^{-1}$ for amplification. Concentrations of DNA extracts from single seeds were too low to quantify, so $1 \mu \mathrm{L}$ extract was used for the amplification.

A protocol similar to the random amplified polymorphic DNA (RAPD) technique (Williams et al., 1990) was used to amplify DNA (Sweeney and Danneberger, 1994). The 25$\mu \mathrm{L}$ amplification reaction mixture $(\mathrm{pH} 8.3)$ contained $20 \mathrm{~mm}$ Tris- $\mathrm{HCl} ; 50 \mathrm{~mm} \mathrm{KCl} ; 3.0$ $\mathrm{mm} \mathrm{MgCl}_{2} ; 0.2 \mu \mathrm{M}$ primer(GGGAGAGGGA); 0.2 mM each dATP, dGTP, dCTP, and dTTP; 1.0 unit Taq DNA polymerase (GIBCO BRL, Grand Island, N.Y.); and up to 5 ng DNA

One-gram samples of common bermudagrass, 'Koket' and 'Banner' chewings fescue, Poa annua, Poa supina 'Supra', 'Cobra' creep-

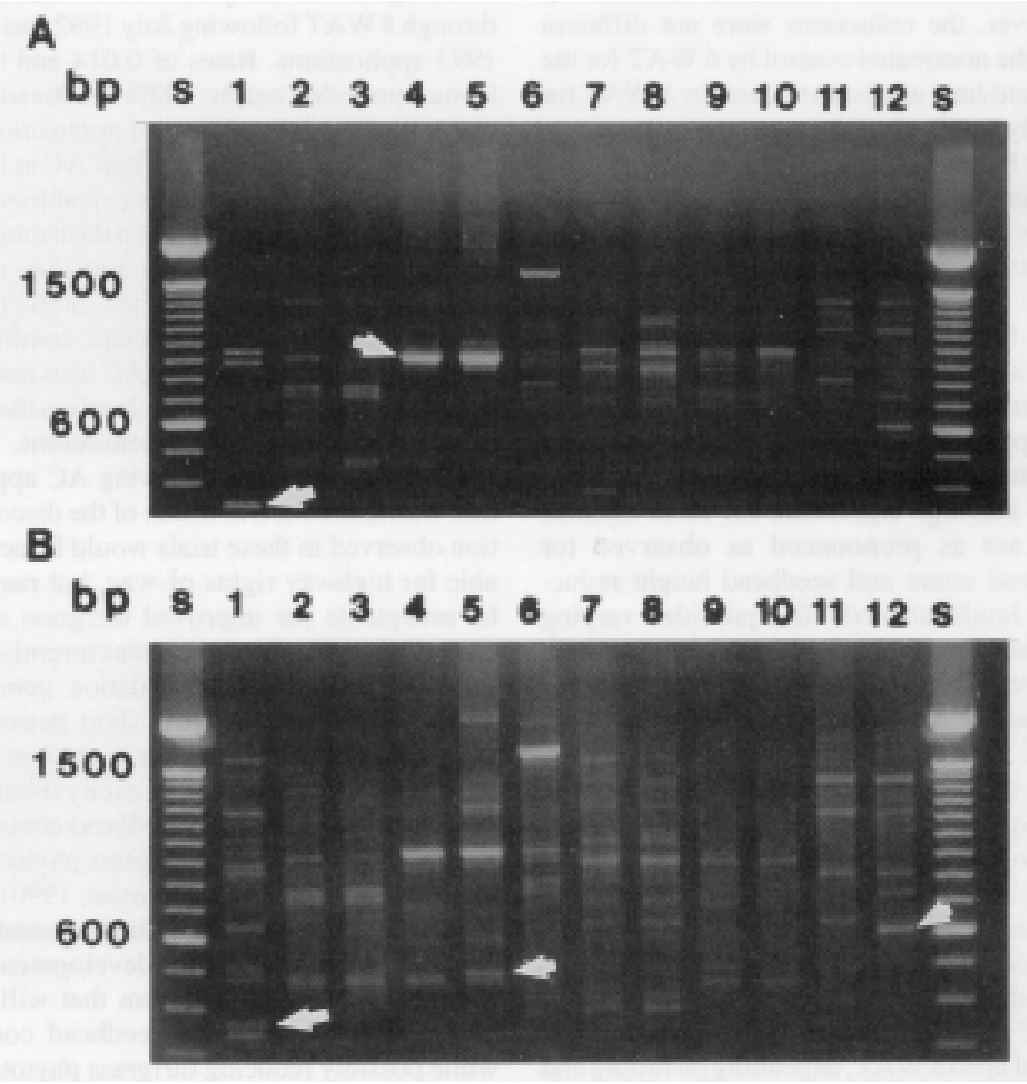

Fig. 1. RAPD banding patterns of DNA extracted from (A) dry single seeds and (B) bulk samples of bermudagrass (lane 1), 'Koket' (lane 2) and 'Banner' (lane 3) chewings fescue, Pоа апnиа (lane 4), Pоа supina 'Supra' (lane 5), 'Cobra' creeping bentgrass (lane 6), 'Caravelle' (lane 7) and 'Accolade' (lane 8) perennial ryegrass, 'Arid' (lane 9) and 'Finelawn 1' (lane 10) tall fescue, and 'Bronco' (lane 11) and 'America' (lane 12) Kentucky bluegrass ( $\mathrm{s}=100$-bp size marker). 
template. Control samples containing all the reagents of the amplification mix except DNA template were included in the experiments. A drop of Sigma (St. Louis) DNAse-free mineral oil was placed over each reaction to prevent volatilization. After $3 \mathrm{~min}$ at 94C, amplification was performed in a thermal cycler (PerkinElmer, Norwalk, Conn.) programmed for 40 cycles of $1 \mathrm{~min}$ at $94 \mathrm{C}, 1 \mathrm{~min}$ at $40 \mathrm{C}$, and $1 \mathrm{~min}$ at $72 \mathrm{C}$. A $15-\mathrm{min}$ extension period at $72 \mathrm{C}$ followed the amplification. Amplification was repeated for each extraction.

Gels containing $1.5 \%$ agarose, ethidium bromide at $0.4 \mathrm{mg} \cdot \mathrm{L}^{-1}$, and TBE ( $89 \mathrm{~mm}$ Trisborate, $89 \mathrm{~mm}$ boric acid, and $2 \mathrm{~mm}$ EDTA) were used to separate amplification products. Loading dye [ $4 \mu \mathrm{L} ; 0.25 \%$ bromophenol blue, $40 \%$ (w/v) sucrose in $\mathrm{H}_{2} \mathrm{O}$ (Sambrook et al., 1989)] was added to each amplification reaction. Samples were vortexed, then centrifuged to separate the amplification reaction mixtures from the overlay of mineral oil. After pipetting $15 \mu \mathrm{L}$ from under the mineral oil and loading it onto the gel, electrophoresis was conducted at $3.4 \mathrm{~V} / \mathrm{cm}$ for $1.5 \mathrm{~h}$. Amplification products were detected under ultraviolet light and photographed.

\section{Results}

In all species evaluated, DNA extracted from both bulk and single-seed samples using the described protocol was successfully amplified (Fig. 1). Amplification was identical for replicate samples of each extraction. Turfgrass DNA extracted from single dry seeds or bulk samples was suitable for amplification. Although strength of the amplification fragments varied among the species, the single primer tested gave reproducible results for all the species evaluated. With an almost infinite number of primers available, finding primers that produce obvious bands to identify varieties likely will be possible for most turfgrass species.

\section{Literature Cited}

Caetano-Anolles, G., B.J. Bassam, and P.M Gresshoff. 1991.DNA amplification fingerprint- ing: A strategy for genome analysis. Plant Mol. Biol. Rpt. 9:294-307.

Edwards, K., C. Johnstone, and C. Thompson. 1991. A simple and rapid method for the preparation of plant genomic DNA for PCR analysis. Nucleic Acids Res. 19:1349.

McDonald, M.B., L.J. Elliot, and P.M. Sweeney. 1994. DNA extraction from dry seeds for RAPD analyses in varietal identification studies. Seed Sci. \& Technol. 22:171-176.

Sambrook, J., E.F. Fritsch, and T. Maniatis. 1989. Molecularcloning: A laboratory manual. Cold Spring Harbor Lab. Press, Cold Spring Harbor, N.Y.

Sweeney, P.M. and T.K. Danneberger. 1994. Random amplified polymorphic DNA in perennial ryegrass: A comparison of bulk samples versus individuals. HortScience 29:624-626.

Turgeon, A.J. 1991. Turfgrass management. Reston Publ. Co., Reston, Va.

Weaver, K.R., L.M. Callahan, G. Caetano-Anolles, and P.M. Gresshoff. 1995. DNA amplification fingerprinting and hybridization analysis of centipedegrass. Crop Sci. 35:881-885.

Williams, J.G.K., A.R. Kubelik, K.J. Livak, J.A Rafalski, and S.V. Tingey. 1990. DNA polymorphisms amplified by arbitrary primers are useful as genetic markers. Nucleic Acids Res. 18:6531-6535. 